\title{
AN ARBORETUM OF ENDEMIC PLANTS OF WESTERN GHATS AT MANGALORE UNIVERSITY CAMPUS, KARNATAKA, INDIA
}

\author{
B.V. Shetty and K.M. Kaveriappa
}

Department of Applied Botany, Mangalore University, Mangalagangothri, Karnataka 574199, India.

\begin{abstract}
Nearly a third of the endemic plant species of the Western Ghats are threatened and are believed to be on the verge of extinction. In situ conservation is known to be the best way to preserve a species but sometimes ex situ proves to be an effective alternative. An arboretum of about three hectares has been established in Mangalore University Campus, Karnataka for the introduction of endemic taxa of the Western Ghats especially those occuring in Karnataka. Fifty-seven taxa of trees, two species of bamboos, 23 species of shrubs including woody climbers and 16 endemic species of herbs/under shrubs have been introduced in the arboretum, the total number of arborescent endemic plants being 2000. The ex situ preservation of these taxa would be a great boon to student community to learn about endemic plants in Western Ghats as well as educate people regarding the need to conserve them. It would also serve as a source material for micro-propagation of rare and threatened plants.
\end{abstract}

\section{Keywords}

Western Ghats, arboretum, Mangalore University

Campus, ex situ conservation, endemic plants

The Western Ghats represent a rich and varied flora with enormous species diversity abound in endemic taxa and therefore recognised (together with Sri Lanka) as one of the 25 Hot Spots in the world (Mittermeier et al., 2000). There are about 54 genera (of which 44 are monotypic), 1720 species and 135 infraspecific taxa of flowering plants endemic to this region (Ahmedullah \& Nayar, 1986; Nair \& Daniel, 1986; Shetty \& Kaveriappa, 1991; Nayar, 1996). Of these over 80 endemic species of trees and shrubs are confined only to the evergreen forests (Pascal, 1988). Sixteen genera of woody plants have five or more endemic species in the Western Ghats e.g. Syzygium (18),

Received on 24 August 2000

Accepted on 10 January 2001
Cinnamomum (12), Garcinia (6), etc. (Ahmedullah \& Nayar, 1986). Nine of the 21 species of Dalbergia reported from the Western Ghats are endemic. Out of about 26 wild species of palms, 22 species, including 18 species of Calamus (Renuka, 1992), are endemic. Endemic gymnosperms are represented by Gnetum contractum Markgraf and Negeia wallichiana (Presl.) Kuntz (= Podocarpus wallichiana Presl.), the latter being the only naturally occurring conifer of peninsular India.

Since the endemic plants are found in restricted areas often requiring special niche for survival, many of them, particularly those with very restricted distribution, are extinction prone, especially if their habitats are disturbed. Nearly a third of the endemic plant species of the Western Ghats are rare or threatened and several are believed to be extinct or on the verge of becoming so, including tree species like Phaeanthus malabaricus Beddome, Sageraea grandiflora Dunn (Annonaceae), Hopea jacobii C. Fischer (Dipterocarpaceae), Buchanania barberi Gamble, Nothopegia aureo-fulva Beddome ex Hook.f. (Anacardiaceae), Calliandra cynometroides Beddome, Cynometra beddomei Prain, Dialium travancoricum Bourd. (Leguminosae), Eugenia argentea Beddome, E. singampattiana Beddome, Syzygium bourdillonii (Gamble) Rathl. \& Nair, $S$. courtallense (Gamble) Alston, S. gambleanum Rathakr. \& Chitra, S. palghatense Gamble (Myrtaceae), Actinodaphne bournae Gamble (Lauraceae), Pseudoglochidion anamalayanum Gamble (Euphorbiaceae), etc.

Although in situ conservation is the best way to preserve a species, in view of the persisting threats to the flora of the Western Ghats because of the various anthropogenic activities, it may not always be feasible to resort to this course, and ex situ preservation may sometimes prove to be an effective alternative. Thanks to the financial assistance from John, D. and Catherine, T. MacArthur Foundation, Chicago, U.S.A. (1992-1994), an arboretum extending over an area of about three hectares has been established in Mangalore University Campus, Karnataka for the introduction of the endemic taxa of the Western Ghats, especially those occuring in the Karnatak region. Introduction of additional taxa in the arboretum is being continued. 
In all 57 taxa of trees, two species of bamboos (Table 1) and 23 species of shrubs, including woody climbers (Table 2) have so far been introduced in the arboretum, the total number of arborescent endemic plants in the arboretum being over 2000. In addition, 16 endemic species of herbs/under shrubs (Table 3 ) are also being maintained in the arboretum. Of the above, the following species are reported to be rare/threatened.

\section{Trees}

Holigarna grahamii (Wight) Kurz (Anacardiaceae)

Hopea canarensis Hole (Dipterocarpaceae)

Myristica fatua Houtt. var. magnifica (Beddome) Sinclair (Myristicaceae)

M. malabarica Lam. (Myristicaceae)

Pterospermum reticulatum Wight \& Arn. (Sterculiaceae)

Vepris bilocularis (Wight \& Arn.) Engl. (Rutaceae)

\section{Scandent shrubs}

Aspidopteris canarensis Dalz. (Malpighiaceae)

Grewia heterotricha Masters (Tiliceae)

Rubus fockei Gandhi (Rosaceae)

Herbs

Crotalaria lutescens Dalz. (Papilionaceae)

Paracautleya bhatii R.M. Smith (Zingiberaceae)

It is also of interest to note that the following monotypic genera, endemic to the Western Ghats, are represented in the arboretum. The name of the solitary species under each genus is mentioned against the respective genus:

Blepharistemma Wallich ex Benth. (Rhizophoraceae)
$\quad$ - B. mambranifolia (Miq.) Ding Hou
Moullava Adans. (Caesalpiniaceae)
$\quad$ - M. spicata (Dalz.) Nicolson
Otonephelium Radlk. (Sapindaceae)
- O. stipulaceum (Beddome) Radlk.
Paracautleya R.M. Smith (Zingiberaceae)
- P. bhatii R.M. Smith

In addition, Poeciloneuron Beddome (Guttiferae), a genus endemic to the Western Ghats with two species, is represented in the arboretum by $P$. indicum Beddome.

Several endemic species in the arboretum are of economic importance and include timber yielding plants e.g. Artocarpus hirsutus Lam., Dipterocarpus indicus Beddome, Hopea parviflora Beddome, Kingiodendron pinnatum (Roxb. ex DC.) Harms., Poeciloneuron indicum Beddome, Vateria indica L., etc.; plants used for weaving baskets, for making furniture and in handicrafts e.g. Calamus nagabettai Fernandez \& Dey, Ochlandra scriptoria (Dennst.) C. Fischer, O. travancorica Gamble etc.; plants yielding gums and resins e.g. Garcinia gummi-gutta (L.) N. Robson, Holigarna ferruginea Marchand, H. grahamii (Wight) Kurz, H. nigra Bourd., Vateria indica L. etc.; plants yielding paper pulp e.g. Garcinia indica Choisy, Ochlandra travancorica Gamble, Vateria indica L., etc., plants yielding edible fruits, e.g. Artocarpus hirsutus Lam., Baccaurea courtallensis Muell.-Arg., Flacourtia montana Graham, Garcinia gummi-gutta (L.) N. Robson, G. indica Choisy, etc; and plants of medicinal importance e.g. Calophyllum apetalum Willd., Hydnocarpus pentandra (Buch.-Ham.) Oken, Hymenodictyon obovatum Wallich, Memecylon malabaricum (C.B. Clake) Cogn., etc.

The ex situ preservation of some of the endemic, rare and threatened plants of the Western Ghats of Karnataka in the arboretum will not only help in educating the people, particularly the student community, about the diversity of plants in the Western Ghats and the need to conserve them but can also serve as a source material for micro-propagation of rare and threatened plants. In this connection it may be noted that successful micropropagation of some endemic species has been undertaken in the laboratory using the material from the arboretum.

\section{Acknowledgements}

The authors are indebted to the MacArthur Foundation, Chicago, U.S.A. for the financial assistance. They are also grateful to Dr. K.G. Bhat, Poornaprajna College, Udupi, Karnataka, and Messrs. H. Soorya Prakasha Shenoy, P. Rama Bhat and K. Purushotham of this department for their help in the collection of endemic taxa.

\section{References}

Ahmedullah, M. and M.P. Nayar (1986). Endemic Plants of the Indian Region I. Botanical Survey of India, Calcutta, 261 pp.

Mittermeier, R.A., N. Myers, P.R. Gil and C.G. Mittermeier (2000). Hotspots: Earth's Biologically Richest and most Endangered Terrestrial Ecoregions. Cemex, Conservation International, Washington D.C., 430 pp.

Nair, N.C. and P. Daniel (1986). The floristic diversity of the Western Ghats and its conservation: A review. Proceedings of the Indian Academy of Sciences (Animal Science/Plant Science) Supplement 127163.

Nayar, M.P. (1996). Hot spots of Endemic Plants of India, Nepal and Bhutan. Tropical Botanical Garden and Research Institute, Thiruvananthapuram, pp. 254.

Pascal, J.P. (1988). Wet Evergreen Forests of the Western Ghats of India. Institut Francais De Pondichery, Travaux de la Section Scientifique et Technique 20, 345 pp.

Renuka, C. (1992). Rattans of the Western Ghats - A Taxonomic Manual. Kerala Forest Research Institute, Peechi, 61 pp.

Shetty, B.V. and K.M. Kaveriappa (1991). The Western Ghats need for preservation. In: Perspectives on Dakshina Kannada and Kodagu. Mangalore University Decennial Volume, 258-272, Mangalagangothri. 
Table 1. List of endemic tree taxa in the Mangalore University arboretum.

\begin{tabular}{|c|c|c|c|c|}
\hline Name of the species & Family & Source & \# Plants & Remarks \\
\hline Actinodaphne malabarica Balakr. & Lauraceae & $\begin{array}{l}\text { Gersoppa and Kaiga, Uttara Kannada, } \\
\text { Karnataka }\end{array}$ & 38 & $\begin{array}{l}\text { Endemic to Western Ghats - In semi-evergreen forests up to } 900 \mathrm{~m} \text {. } \\
\text { Karnataka, Kerala and Tamil Nadu. }\end{array}$ \\
\hline Aglaia lawii (Wight) Saldanha & Meliaceae & Kudremukh, Chickamagalur, Karnataka & 41 & $\begin{array}{l}\text { Endemic to Western Ghats - Maharashtra, Goa, Karnataka, Kerala and } \\
\text { Tamil Nadu. }\end{array}$ \\
\hline Arenga wightii Griffith & Plamae & Gersoppa, Uttara Kannada, Karnataka & 21 & $\begin{array}{l}\text { Endemic to Western Ghats - In evergreen forests between 150-900m. } \\
\text { Karnataka, Kerala and Tamil Nadu. }\end{array}$ \\
\hline Artocarpus hirsutus Lam. & Moraceae & Mangalore, Dakshina Kannada, Karnataka & 56 & $\begin{array}{l}\text { Endemic to Western Ghats /western coast - In moist deciduous to semi } \\
\text { evergreen forests up to } 1100 \mathrm{~m} \text {. Maharashtra, Goa, Karnataka, Kerala and } \\
\text { Tamil Nadu. }\end{array}$ \\
\hline Baccaurea courtallensis Muell. - Arg. & Euphorbiaceae & Puttur, Dakshina Kannada, Karnataka & 64 & $\begin{array}{l}\text { Endemic to Western Ghats - In evergreen forests. Karnataka, Kerala and } \\
\text { Tamil Nadu. }\end{array}$ \\
\hline Blepharistemma membranifolia (Miq.) Ding Hou & Rhizophoraceae & Udupi, Dakshina Kannada, Karnataka & 3 & $\begin{array}{l}\text { Endemic to Western Ghats /western coast - Karnataka and Kerala. The } \\
\text { genus Blepharistemma Wallich ex Benth. is monotypic and is endemic to } \\
\text { the Western Ghats region. }\end{array}$ \\
\hline Calophyllum apetalum Willd. & Guttiferaceae & $\begin{array}{l}\text { Gersoppa and Kaiga, Uttara Kannada, } \\
\text { Karnataka }\end{array}$ & 55 & $\begin{array}{l}\text { Endemic to Western Ghats - along river banks in semi-evergreen forests } \\
\text { at low altitudes, up to } 600 \mathrm{~m} \text {. Maharashtra, Goa, Karnataka, Kerala and } \\
\text { Tamil Nadu. }\end{array}$ \\
\hline Cinnamomum malabarum (Burm. f.) Blume & Lauraceae & Gersoppa, Uttara Kannada, Karnataka & 47 & $\begin{array}{l}\text { Endemic to southern Western Ghats - In moist deciduous to evergreen } \\
\text { forests. Karnataka, Kerala and Tamil Nadu. }\end{array}$ \\
\hline Cleistanthus malabaricus (Muell.-Arg.) & Euphorbiaceae & Gersoppa, Uttara Kannada, Karnataka & 32 & $\begin{array}{l}\text { Endemic to Western Ghats - near river banks in evergreen forests between } \\
\text { 900-1300m. Karnataka, Kerala and Tamil Nadu }\end{array}$ \\
\hline Croton malabaricus Beddome & Euphorbiaceae & Gersoppa, Uttara Kannada, Karnataka & 9 & $\begin{array}{l}\text { Endemic to Western Ghats - In semi-evergreen to evergreen forests } \\
\text { between } 900-1300 \mathrm{~m} \text {. Karnataka, Kerala and Tamil Nadu }\end{array}$ \\
\hline Diospyros paniculata Dalz. & Ebenaceae & Gersoppa, Uttara Kannada, Karnataka & 43 & $\begin{array}{l}\text { Endemic to Western Ghats - In evergreen forests up to } 900 \mathrm{~m} \text {. Maharashtra, } \\
\text { Goa, Karnataka, Kerala and Tamil Nadu }\end{array}$ \\
\hline Diospyros pruriens Dalz. & Ebenaceae & Gersoppa, Uttara Kannada, Karnataka & 4 & $\begin{array}{l}\text { Endemic to Western Ghats - In semi-evergreen to evergreen forests up to } \\
\text { 900m. Maharashtra, Goa, Karnataka, Kerala and Tamil Nadu }\end{array}$ \\
\hline Diospyros saldanhae Kosterm. & Ebenaceae & Gersoppa, Uttara Kannada, Karnataka & 12 & $\begin{array}{l}\text { Endemic to Western Ghats - In moist deciduous to semi-evergreen forests. } \\
\text { Karnataka and Kerala }\end{array}$ \\
\hline Dipterocarpus indicus Beddome & Dipterocarpaceae & $\begin{array}{l}\text { Gersoppa, Uttara Kannada, Karnataka } \\
\text { Sampaje, Kodagu, Karnataka }\end{array}$ & 48 & $\begin{array}{l}\text { Endemic to Western Ghats - In evergreen to semi-evergreen forests up to } \\
1000 \mathrm{~m} \text {. Karnataka, Kerala and Tamil Nadu. }\end{array}$ \\
\hline Drypetes confertiflora (Hook.f.) Pax \& Hoffm. & Euphorbiaceae & Gersoppa, Uttara Kannada, Karnataka & 18 & Endemic to Western Ghats - In evergreen forests. Karnataka and Kerala \\
\hline Epiprinus mallotiformis (Muell. -Arg.) Croizat & Euphorbiaceae & Gersoppa, Uttara Kannada, Karnataka & 43 & $\begin{array}{l}\text { Endemic to Western Ghats - In semi-evergreen and evergreen forests up } \\
\text { to } 1000 \mathrm{~m} \text {. Karnataka, Kerala and Tamil Nadu. }\end{array}$ \\
\hline Euonymus indicus Heyne ec Wallich & Celastraceae & Sringeri, Chickamagalur, Karnataka & 5 & $\begin{array}{l}\text { Endemic to Western Ghats - In moist deciduous to evergreen forests up to } \\
\text { 1300m. Maharashtra, Goa, Karnataka, Kerala and Tamil Nadu. }\end{array}$ \\
\hline
\end{tabular}




\begin{tabular}{|c|c|c|c|c|}
\hline Name of the species & Family & Source & \# Plants & Remarks \\
\hline Flacourtia montana Graham & Flacourtiaceae & Mangalore, Dakshina Kannada, Karnataka & 44 & $\begin{array}{l}\text { Endemic to Western Ghats - In moist deciduous to semi-evergreen forests } \\
\text { up to } 1000 \mathrm{~m} \text {. Maharashtra, Goa, Karnataka, Kerala and Tamil Nadu. }\end{array}$ \\
\hline Garcinia gummi-gutta (L.) N. Robson & Guttiferae & Gersoppa, Uttara Kannada, Karnataka & 42 & $\begin{array}{l}\text { Endemic to Western Ghats - In semi-evergreen, evergreen and shola } \\
\text { forests up to } 1830 \mathrm{~m} \text {. Maharashtra, Goa, Karnataka, Kerala and Tamil } \\
\text { Nadu. }\end{array}$ \\
\hline Garcinia indica (Thouars) Choisy & Guttiferae & $\begin{array}{l}\text { Mangalore, Dakshina Kannada, Karnataka } \\
\text { Gersoppa, Uttara Kannada, Karnataka }\end{array}$ & 45 & $\begin{array}{l}\text { Endemic to Western Ghats - In evergreen and deciduous forests up to } \\
\text { 400m. Maharashtra, Goa, Karnataka, Kerala and Tamil Nadu. }\end{array}$ \\
\hline Glochidion ellipticum Wight & Euphorbiaceae & Gersoppa, Uttara Kannada, Karnataka & 36 & $\begin{array}{l}\text { Endemic to Western Ghats - In evergreen forests up to 1300m. Karnataka, } \\
\text { Kerala and Tamil Nadu. }\end{array}$ \\
\hline Glochidion johnstonei Hook.f. & Euphorbiaceae & Gersoppa, Uttara Kannada, Karnataka & 16 & $\begin{array}{l}\text { Endemic to Western Ghats/W.coast - In moist forests up to } 600 \mathrm{~m} \text {. } \\
\text { Maharashtra, Karnataka and Kerala. }\end{array}$ \\
\hline Glochidion neilgherrense Wight & Euphorbiaceae & Gersoppa, Uttara Kannada, Karnataka & 28 & $\begin{array}{l}\text { Endemic to Western Ghats - In shola and evergreen forests up to 2300m. } \\
\text { Karnataka, Kerala and Tamil Nadu. }\end{array}$ \\
\hline Gordonia obtusa Walich ex Wight \& Arn. & Theaceae & Kudremukh, Chickamagalur, Karnataka & 37 & $\begin{array}{l}\text { Endemic to Western Ghats - In shola and evergreen forests between 500- } \\
2100 \mathrm{~m} \text {. Maharashtra, Goa, Karnataka, Kerala and Tamil Nadu. }\end{array}$ \\
\hline $\begin{array}{l}\text { Gymnacrantherafarquhariana } \\
\text { (Hook.f. ex Thomson) Warb. }\end{array}$ & Myristicaceae & $\begin{array}{l}\text { Madikeri, Kodagu, Karnataka } \\
\text { Gersoppa, Uttara Kannada, Karnataka }\end{array}$ & 25 & $\begin{array}{l}\text { Endemic to Western Ghats - In semi-evergreen to evergreen forests. } \\
\text { Karnataka and Kerala. }\end{array}$ \\
\hline Holigarna arnottiana Hook.f. & Anacardiaceae & Gersoppa, Uttara Kannada, Karnataka & 7 & $\begin{array}{l}\text { Endemic to Western Ghats/W. coast - In semi-evergreen forests. } \\
\text { Maharashtra, Goa, Karnataka, Kerala and Tamil Nadu. }\end{array}$ \\
\hline *Holigarna ferruginea Marchand & Anacardiaceae & Mangalore, Dakshina Kannada, Karnataka & 31 & $\begin{array}{l}\text { Endemic to Western Ghats -In semi-evergreen to evergreen forests. Goa, } \\
\text { Karnataka, Kerala and Tamil Nadu. }\end{array}$ \\
\hline Holigarna grahamii (Wight) Kurz & Anacardiaceae & $\begin{array}{l}\text { Gersoppa, Uttara Kannada, Karnataka } \\
\text { Kaiga, Uttara Kannada, Karnataka }\end{array}$ & 37 & $\begin{array}{l}\text { Endemic to Western Ghats -In moist deciduous to evergreen forests. } \\
\text { Maharashtra, Karnataka, Kerala and Tamil Nadu. Rare (Ahmedullah \& } \\
\text { Nayar, 1986). }\end{array}$ \\
\hline Holigarna nigra Bourd. & Anacardiaceae & Kudremukh, Chickamagalur, Karnataka & 35 & $\begin{array}{l}\text { Endemic to Western Ghats -In evergreen forests between 650-1250m. } \\
\text { Karnataka, Kerala and Tamil Nadu. }\end{array}$ \\
\hline Hopea canarensis Hole & Dipterocarpaceae & Kudremukh, Chickamagalur, Karnataka & 16 & $\begin{array}{l}\text { Endemic to Western Ghats - Karnataka. Rare and threatened (Ahmedullah } \\
\text { \& Nayar, 1986). }\end{array}$ \\
\hline Hopea parviflora Beddome & Dipterocarpaceae & $\begin{array}{l}\text { Gersoppa, Uttara Kannada, Karnataka } \\
\text { Kundapur, Dakshina Kannada, Karnataka }\end{array}$ & 59 & $\begin{array}{l}\text { Endemic to Western Ghats - In wet forests up to } 1100 \mathrm{~m} \text {. Karnataka, } \\
\text { Kerala and Tamil Nadu }\end{array}$ \\
\hline Hopea ponga (Dennst.) Mabb. & Dipterocarpaceae & Gersoppa, Uttara Kannada, Karnataka & 32 & $\begin{array}{l}\text { Endemic to Western Ghats/western Coast-In semi-evergreen to evergreen } \\
\text { forests up to } 1500 \mathrm{~m} \text {. Maharashtra, Goa, Karnataka, Kerala and Tamil } \\
\text { Nadu. }\end{array}$ \\
\hline Hydnocarpus pentandra (Buch.-Ham.) Oken & Flacourtiaceae & $\begin{array}{l}\text { Mangalore, Dakshina Kannada, Karnataka } \\
\text { Kaiga and Gersoppa, Uttara Kannada, } \\
\text { Karnataka }\end{array}$ & 42 & $\begin{array}{l}\text { Endemic to Western Ghats - In moist deciduous and semi-evergreen } \\
\text { forests up to } 850 \mathrm{~m} \text {. Maharashtra, Goa, Karnataka, Kerala and Tamil Nadu }\end{array}$ \\
\hline Hyphaene dichotoma (White) Furtado & Palmae & Goa & 6 & Endemic to Diu, Daman, coast of Gujarat, northern Maharashtra and Goa. \\
\hline
\end{tabular}




\begin{tabular}{|c|c|c|c|c|}
\hline Name of the species & Family & Source & \# Plants & Remarks \\
\hline $\begin{array}{l}\text { Hymenodictyon orixense (Roxb.)Mabberly } \\
\text { (= Hymenodictyon obovatum Wallich) }\end{array}$ & Rubiaceae & Udupi, Dakshina Kannada, Karnataka & 5 & $\begin{array}{l}\text { Endemic to Western Ghats - In deciduous forests up to 1200m. Maharashtra, } \\
\text { Goa, Karnataka, Kerala and Tamil Nadu }\end{array}$ \\
\hline Ilex malabarica Beddome & Aquifoliaceae & Gersoppa, Uttara Kannada, Karnataka & 3 & Western Ghats - Maharashtra, Goa, Karnataka, Kerala and Tamil Nadu. \\
\hline Ixora brachiata Roxb. & Rubiaceae & Gersoppa, Uttara Kannada, Karnataka & 37 & Western Ghats - Maharashtra, Goa, Karnataka, Kerala and Tamil Nadu. \\
\hline Kingiodendron pinnatum (Roxb. ex DC.) Harms & Caesalpiniaceae & Sampaje, Kodagu, Karnataka & 40 & $\begin{array}{l}\text { Endemic to Western Ghats - In evergreen forests up to } 900 \mathrm{~m} \text {. Karnataka, } \\
\text { Kerala and Tamil Nadu }\end{array}$ \\
\hline Knema attenuata (Hook.f. \& Thomson) Warb. & Myristicaceae & Gersoppa, Uttara Kannada, Karnataka & 25 & $\begin{array}{l}\text { Endemic to Western Ghats - In semi-evergreen and evergreen forests } \\
\text { between } 1000 \mathrm{~m} \text {. Maharashtra, Goa, Karnataka, Kerala and Tamil Nadu. }\end{array}$ \\
\hline Lagerstroemia microcarpa Wight & Lythraceae & Gersoppa, Uttara Kannada, Karnataka & 43 & $\begin{array}{l}\text { Endemic to Western Ghats - In moist deciduous to semi-evergreen forests } \\
\text { up to } 1000 \mathrm{~m} \text {. Maharashtra, Goa, Karnataka, Kerala and Tamil Nadu. }\end{array}$ \\
\hline Mastixia arborea (Wight) Beddome & Cornaceae & $\begin{array}{l}\text { Gersoppa and Kaiga, Uttara Kannada, } \\
\text { Karnataka }\end{array}$ & 30 & $\begin{array}{l}\text { Endemic to Western Ghats - In evergreen forests. Maharashtra, Goa, } \\
\text { Karnataka, Kerala and Tamil Nadu }\end{array}$ \\
\hline *Memecylon malabaricum (C.B. Clarke) Cogn. & Melastomataceae & $\begin{array}{l}\text { Mangalore and Udupi, Dakshina Kannada } \\
\text { Karnataka }\end{array}$ & 25 & $\begin{array}{l}\text { Endemic to Western Ghats / western coast - In moist deciduous to } \\
\text { evergreen forests up to } 1800 \mathrm{~m} \text {. Karnataka, Kerala and Tamil Nadu. }\end{array}$ \\
\hline *Memecylon talbotianum Brandis & Melastomataceae & $\begin{array}{l}\text { Mangalore, Dakshina Kannada, Karnataka } \\
\text { Gersoppa, Uttara Kannada, Karnataka }\end{array}$ & 25 & $\begin{array}{l}\text { Endemic to Western Ghats/western coast-In moist deciduous to evergreen } \\
\text { forests up to } 1800 \mathrm{~m} \text {. Maharashtra, Goa, Karnataka, Kerala and Tamil } \\
\text { Nadu. }\end{array}$ \\
\hline $\begin{array}{l}\text { Myristica fatua Houtt. var. magnifica } \\
\text { (Beddome) Sinclair }\end{array}$ & Myristicaceae & Gersoppa, Uttara Kannada, Karnataka & 50 & $\begin{array}{l}\text { Endemic to Western Ghats - In swampy areas of evergreen forests. } \\
\text { Karnataka, Kerala and Tamil Nadu. Rare and threatened (Ahmedullah \& } \\
\text { Nayar, 1986) }\end{array}$ \\
\hline Myristica malabarica Lam. & Myristicaceae & $\begin{array}{l}\text { Gersoppa, Uttara Kannada, Karnataka } \\
\text { Hosmata, Dakshina Kannada, Karnataka }\end{array}$ & 31 & $\begin{array}{l}\text { Endemic to W. Ghats - In evergreen forests up to } 800 \mathrm{~m} \text {. Maharshtra, } \\
\text { Karnataka and Kerala. Rare and threatened (Ahmedullah \& Nayar, 1986). }\end{array}$ \\
\hline $\begin{array}{l}\text { Ochreinauclea missionis } \\
\text { (Wallich ex G. Don) Ridsd. }\end{array}$ & Rubiaceae & Udupi, Dakshina Kannada, Karnataka & 14 & $\begin{array}{l}\text { Endemic to Western Ghats /western coast - on river banks up to } 450 \mathrm{~m} \text {. } \\
\text { Goa, Karnataka, Kerala and Tamil Nadu. }\end{array}$ \\
\hline Otonephelium stipulaceum (Beddome) Radlk. & Sapindaceae & Karike, Kodagu, Karnataka & 30 & $\begin{array}{l}\text { Endemic to Western Ghats - In evergreen forests. Karnataka, Kerala and } \\
\text { Tamil Nadu. }\end{array}$ \\
\hline Pandanus unipapillata Warb. & Pandanaceae & Udupi, Dakshina Kannada, Karnataka & 4 & Endemic to western coast. \\
\hline Pinanga dicksonii (Roxb.) Blume & Palmae & Gersoppa, Uttara Kannada, Karnataka & 17 & $\begin{array}{l}\text { Endemic to Western Ghats - In evergreen forests. Karnataka, Kerala and } \\
\text { Tamil Nadu }\end{array}$ \\
\hline Poeciloneuron indicum Beddome & Guttiferae & Kudremukh, Chickamagalur, Karnataka & 35 & $\begin{array}{l}\text { Endemic to southern Western Ghats - In evergreen forests up to } 1200 \mathrm{~m} \text {. } \\
\text { Karnataka, Kerala and Tamil Nadu }\end{array}$ \\
\hline Polyalthia fragrans (Dalz.) Beddome & Annonaceae & Gersoppa, Uttara Kannada, Karnataka & 45 & $\begin{array}{l}\text { Endemic to Western Ghats - In semi-evergreen to evergreen forests up to } \\
\text { 1200m. Maharashtra, Karnataka, Kerala and Tamil Nadu }\end{array}$ \\
\hline Pterospermum reticulatum Wight \& Arn. & Sterculiaceae & Gersoppa, Uttara Kannada, Karnataka & 46 & $\begin{array}{l}\text { Endemic to Western Ghats - In evergreen forests at low elevations. } \\
\text { Karnataka, Kerala and Tamil Nadu. Rare and threatened (Ahmedullah \& } \\
\text { Nayar, 1986) }\end{array}$ \\
\hline Syzygium laetum (Buch.-Ham.) Gandhi & Myrtaceae & Gersoppa, Uttara Kannada, Karnataka & 21 & Endemic to Western Ghats - In evergreen forests between $200-900 \mathrm{~m}$. \\
\hline
\end{tabular}




\begin{tabular}{|c|c|c|c|c|}
\hline Name of the species & Family & Source & \# Plants & Remarks \\
\hline & & & & Maharshtra, Karnataka, Kerala and Tamil Nadu. \\
\hline `Tabernaemontana heyneana Wallich & Apocynaceae & Mangalore, Dakshina Kannada, Karnataka & 20 & $\begin{array}{l}\text { Endemic to Western Ghats /western coast- In open forests up to } 900 \mathrm{~m} \text {. } \\
\text { Maharshtra, Goa, Karnataka, Kerala and Tamil Nadu. }\end{array}$ \\
\hline Trewia polycarpa Benth. & Euphorbiaceae & B.C. Road, Dakshina Kannada, Karnataka & 20 & $\begin{array}{l}\text { Endemic to Western Ghats / western coast - along river banks and } \\
\text { streams at low altitudes. Maharshtra, Goa, Karnataka, Kerala and Tamil } \\
\text { Nadu. }\end{array}$ \\
\hline •Vateria indica L. & Dipterocarpaceae & $\begin{array}{l}\text { Hosmata and Mangalore, } \\
\text { Dakshina Kannada, Karnataka }\end{array}$ & 35 & $\begin{array}{l}\text { Endemic to Western Ghats / western coast- usually in evergreen forests } \\
\text { up to } 1300 \mathrm{~m} \text {. Karnataka, Kerala and Tamil Nadu. }\end{array}$ \\
\hline Vepris bilocularis (Wight \& Arn.) Engl. & Rutaceae & Gersoppa, Uttara Kannada, Karnataka & 50 & $\begin{array}{l}\text { Endemic to Western Ghats - In semi-evergreen forests up to } 1300 \mathrm{~m} \text {. } \\
\text { Karnataka, Kerala and Tamil Nadu. Rare (Ahmedullah \& Nayar, 1986). }\end{array}$ \\
\hline \multicolumn{5}{|l|}{ Bamboos } \\
\hline Ochlandra scriptoria (Dennst.) C. Fischer & Graminae & Udupi, Dakshina Kannada, Karnataka & 10 & $\begin{array}{l}\text { Endemic to Western Ghats / western coast - on river and stream banks at } \\
\text { low elevations. Karnataka and Kerala. }\end{array}$ \\
\hline Ochlandra travancorica Benth. ex Gamble & Graminae & Gersoppa, Uttara Kannada, Karnataka & 14 & $\begin{array}{l}\text { Endemic to southern Western Ghats - gregarious in evergreen forests up } \\
\text { to } 1500 \mathrm{~m} \text {. Karnataka, Kerala and Tamil Nadu. }\end{array}$ \\
\hline
\end{tabular}

* Plants of these species also occur naturally in the arboretum area.

Table 2. List of endemic shrub taxa (including scandent shrubs) in the Mangalore University arboretum.

\begin{tabular}{|c|c|c|c|c|}
\hline Name of the species & Family & Source & \# Plants & Remarks \\
\hline Ancistrocladus heyneanus Wallich ex Grah. & Anistrocladaceae & Gersoppa, Uttara Kannada, Karnataka & 5 & $\begin{array}{l}\text { Endemic to Western Ghats - In evergreen forests. Maharshtra, Karnataka, } \\
\text { Kerala and Tamil Nadu }\end{array}$ \\
\hline Aspidopteris canarensis Dalz. & Malpighiaceae & Udupi, Dakshina Kannada, Karnataka & 5 & $\begin{array}{l}\text { Endemic to Western Ghats/Deccan-In moist deciduous to semi-evergreen } \\
\text { forests. Maharshtra, Karnataka, Kerala and Tamil Nadu. Rare and } \\
\text { threatened (Ahmedullah \& Nayar, 1986). }\end{array}$ \\
\hline Atylosia lineata Wight \& Arn. & Papilionaceae & Gersoppa, Uttara Kannada, Karnataka & 20 & $\begin{array}{l}\text { Endemic to Western Ghats - In moist deciduous forests between 900- } \\
\text { 1500m. Maharshtra, Goa, Karnataka, Kerala and Tamil Nadu. }\end{array}$ \\
\hline Calamus dransfieldii Renuka & Palmae & $\begin{array}{l}\text { Forest nursery, Subramanya, } \\
\text { Dakshina Kannada, Karnataka }\end{array}$ & 10 & $\begin{array}{l}\text { Endemic to Western Ghats - In evergreen forests between 300-700m. } \\
\text { Karnataka, Kerala and Tamil Nadu. }\end{array}$ \\
\hline Calamus hookerianus Becc. & Palmae & K.F.R.I., Peechi, Kerala & 4 & $\begin{array}{l}\text { Endemic to Western Ghats - In evergreen forests up to } 1000 \mathrm{~m} \text {. } \\
\text { Kerala and Tamil Nadu. }\end{array}$ \\
\hline Calamus lakshmanae Renuka & Palmae & $\begin{array}{l}\text { Forest nursery, Sampaje, } \\
\text { Dakshina Kannada, Karnataka }\end{array}$ & 5 & $\begin{array}{l}\text { Endemic to Western Ghats - In evergreen forests at about } 85 \mathrm{~m} \text {. } \\
\text { Karnataka. }\end{array}$ \\
\hline Calamus nagabettai Fernadez \& Dey & Palmae & $\begin{array}{l}\text { Forest nursery, Subramanya, } \\
\text { Dakshina Kannada, Karnataka }\end{array}$ & 42 & $\begin{array}{l}\text { Endemic to Western Ghats - In evergreen forests. Karnataka and } \\
\text { Kerala. }\end{array}$ \\
\hline
\end{tabular}




\begin{tabular}{|c|c|c|c|c|}
\hline Name of the species & Family & Source & \# Plants & Remarks \\
\hline Calamus prasinus Lakshmana \& Renuka & Palmae & $\begin{array}{l}\text { Forest nursery, Subramanya, } \\
\text { Dakshina Kannada, Karnataka }\end{array}$ & 25 & $\begin{array}{l}\text { Endemic to Western Ghats - In evergreen forests at about } 530 \mathrm{~m} \text {. } \\
\text { Karnataka. }\end{array}$ \\
\hline Calamus vattayila Renuka & Palmae & $\begin{array}{l}\text { Forest nursery, Subramanya, } \\
\text { Dakshina Kannada, Karnataka }\end{array}$ & 25 & $\begin{array}{l}\text { Endemic to Western Ghats - In evergreen forests between } 200-750 \mathrm{~m} \text {. } \\
\text { Karnataka, Kerala and Tamil Nadu }\end{array}$ \\
\hline Dalbergia horrida (Dennst.) Mabb. & Papillionaceae & Udupi, Dakshina Kannada, Karnataka & 4 & $\begin{array}{l}\text { Endemic to Western Ghats/western coast-Maharashtra, Goa, } \\
\text { Kartnataka, Kerala and Tamil Nadu. Also in Salem of Eastern Ghats }\end{array}$ \\
\hline Desmos lawii (Hook.f.\& Thomson) Safford & Annonaceae & Gersoppa, Uttara Kannada, Karnataka & 10 & $\begin{array}{l}\text { Endemic to Western Ghats - In evergreen to semi evergreen forests } \\
\text { between 500-900m. Maharashtra, Goa, Kartnataka, Kerala and Tamil } \\
\text { Nadu. }\end{array}$ \\
\hline Flemingia nilgheriensis (Baker) Wight ex Cooke & Papilionaceae & Sringeri, Chickamagalur, Karnataka & 12 & $\begin{array}{l}\text { Endemic to Western Ghats/Bababudan Hills - Maharashtra, Karnataka } \\
\text { and Kerala }\end{array}$ \\
\hline Grewia heterotricha Masters & Tiliaceae & Gersoppa, Uttara Kannada, Karnataka & 33 & $\begin{array}{l}\text { Endemic to Western Ghats - In deciduous to semi evergreen forests. } \\
\text { Maharashtra, Goa, Kartnataka, Kerala and Tamil Nadu. Rare (Ahmedullah } \\
\text { \& Nayar, 1986) }\end{array}$ \\
\hline Gymnostachyum latifolium T. Anderson & Acanthaceae & Gersoppa, Uttara Kannada, Karnataka & 11 & $\begin{array}{l}\text { Endemic to Western Ghats/Bababudan Hills up to 1250m. - Maharashtra, } \\
\text { Karnataka, Kerala and Tamil Nadu. }\end{array}$ \\
\hline Humboldtia brunonis Wallich & Caesalpiniaceae & Subramanya, Dakshina Kannada, Karnataka & 41 & $\begin{array}{l}\text { Endemic to Western Ghats - In evergreen forests up to } 800 \mathrm{~m} \text {. } \\
\text { Karnataka, Kerala and Tamil Nadu. }\end{array}$ \\
\hline Ixora polyantha Wight & Rubiaceae & $\begin{array}{l}\text { Gersoppa, Uttara Kannada, Karnataka. } \\
\text { Udupi, Dakshina Kannada, Karnataka }\end{array}$ & 11 & $\begin{array}{l}\text { Endemic to Western Ghats/western coast-Maharashtra, Kartnataka and } \\
\text { Kerala. }\end{array}$ \\
\hline Lasianthus parvifolius Wight & Rubiaceae & Sringeri, Chickamagalur, Karnataka & 5 & Endemic to Western Ghats - Karnataka and Tamil Nadu. \\
\hline Moullava spicata (Dalz.) Nicolson & Caesalpiniaceae & Gersoppa, Uttara Kannada, Karnataka & 5 & $\begin{array}{l}\text { Endemic to Western Ghats - up to } 900 \mathrm{~m} \text {. Karnataka and Kerala. The } \\
\text { genus Moullava Adans. is monotypic and is endemic to the Western } \\
\text { Ghats. }\end{array}$ \\
\hline Psychotria dalzelli Hook.f. & Rubiaceae & Kaiga, Uttara Kannada, Karnataka & 4 & $\begin{array}{l}\text { Endemic to Western Ghats/western coast - Maharashtra, Kartnataka } \\
\text { and Kerala }\end{array}$ \\
\hline Psychotria flavida Talbot & Rubiaceae & Udupi, Dakshina Kannada, Karnataka & 25 & $\begin{array}{l}\text { Endemic to Western Ghats/western coast - Maharashtra, Kartnataka, } \\
\text { Kerala and Tamil Nadu }\end{array}$ \\
\hline Rubus fockei Gandhi & Rosaceae & Sringeri, Chickamagalur, Karnataka & 5 & $\begin{array}{l}\text { Endemic to Western Ghats/Bababudan and Biligirirangan Hills- } \\
\text { In evergreen forests. Karnataka and Kerala. Rare and threatened } \\
\text { (Ahmedullah \& Nayar, 1986). }\end{array}$ \\
\hline Spatholobus purpureus Benth. ex Baker & Papilionaceae & Gersoppa, Uttara Kannada, Karnataka & 5 & $\begin{array}{l}\text { Endemic to Western Ghats - In evergreen forests. Maharashtra, } \\
\text { Karnataka, Kerala and Tamil Nadu. }\end{array}$ \\
\hline Tetrastigma gamblei Shetty \& P. Singh & Vitaceae & Gersoppa, Uttara Kannada, Karnataka & 12 & $\begin{array}{l}\text { Endemic to Western Ghats - In evergreen forests. Maharashtra, } \\
\text { Karnataka and Kerala. }\end{array}$ \\
\hline
\end{tabular}


Table 3. List of endemic herb taxa in the Mangalore University arboretum.

\begin{tabular}{|c|c|c|c|c|}
\hline Name of the species & Family & Sources & \# Plants & Remarks \\
\hline Amomum cannicarpum (Wight) Benth. & Zingiberaceae & Jodupala, Kodagu, Karnataka & 2 & $\begin{array}{l}\text { Endemic to Western Ghats - In evergreen forests up to } 1800 \mathrm{~m} \text {. } \\
\text { Karnataka, Kerala and Tamil Nadu }\end{array}$ \\
\hline Amomum ghaticum K.G. Bhat & Zingiberaceae & Sulkirimogru, Dakshina Kannada, Karnataka & 5 & Endemic to Western Ghats \\
\hline Amomum muricatum Beddome & Zingiberaceae & Agumbe, Shimoga & 2 & $\begin{array}{l}\text { Endemic to Western Ghats - In evergreen forests between } 500-900 \mathrm{~m} \text {. } \\
\text { Karnataka, Kerala and Tamil Nadu }\end{array}$ \\
\hline Amorphophallus commutatus (Schott) Engl. & Araceae & Udupi, Dakshina Kannada, Karnataka & 3 & Endemic to Western Ghats - Maharashtra and Karnataka \\
\hline Andrographis lineata Nees & Acanthaceae & Sringeri, Chickamagalur, Karnataka & $>100$ & $\begin{array}{l}\text { Endemic to Western Ghats - Tamil Nadu and Karnataka. Also in } \\
\text { Cuddapah, Andhra Pradesh. }\end{array}$ \\
\hline Asystasia dalzelliana Santapau & Acanthaceae & Goa & $>100$ & $\begin{array}{l}\text { Endemic to Western Ghats -At low altitudes. Goa, Kerala, Tamil } \\
\text { Nadu and Karnataka }\end{array}$ \\
\hline Bulbophyllum neilgherrense Wight & Orchidaceae & Seethanadi, Dakshina Kannada, Karnataka & 10 & $\begin{array}{l}\text { Endemic to Western Ghats - up to } 1800 \mathrm{~m} \text {. Maharashtra,Goa, } \\
\text { Kerala, Tamil Nadu and Karnataka }\end{array}$ \\
\hline Crotalatria filipes Benth. & Papilionaceae & Gersoppa, Uttara Kannada, Karnataka & 10 & Endemic to Western Ghats/western coast-Maharashtra and Kartnataka \\
\hline Crotalatria lutescens Dalz. & Papilionaceae & Udupi, Dakshina Kannada, Karnataka & $>100$ & $\begin{array}{l}\text { Endemic to Western Ghats/western coast-Maharashtra and Kartnataka. } \\
\text { Rare and threatened (Ahmedullah \& Nayar, 1986) }\end{array}$ \\
\hline Ensete superbum (Roxb.) Cheesman & Musaceae & $\begin{array}{l}\text { Agumbe, Shimoga, Karnataka. } \\
\text { Kaiga, Uttara Kannada, Karnataka }\end{array}$ & 12 & Endemic to Western Ghats, extending up to Gujarat, $900-1500 \mathrm{~m}$. \\
\hline Frerea indica Dalz. & Asclepiadaceae & Botany department, Goa University, Goa & 6 & $\begin{array}{l}\text { Endemic to northern Western Ghats of Central Maharashtra. Rare } \\
\text { and threatened (Ahmedullah \& Nayar, 1986) }\end{array}$ \\
\hline Paracautleya bhattii R.M. Smith & Zingiberaceae & Udupi, Dakshina Kannada, Karnataka & 8 & $\begin{array}{l}\text { Endemic to Western Ghats /western coast-Karnataka. The genus } \\
\text { Paracautleya R.M. Smith is monotypic. }\end{array}$ \\
\hline Pouzolzia wightii Bennet & Urticaceae & Sringeri, Chickamagalur, Karnataka & 3 & Endemic to Peninsular India \\
\hline Trias stocksii Benth. & Orchidaceae & Sringeri, Chickamagalur, Karnataka & 3 & $\begin{array}{l}\text { Endemic to Western Ghats - Maharashtra, Karnataka, Kerala and } \\
\text { Tamil Nadu }\end{array}$ \\
\hline Zingiber cernuum Dalz. & Zingiberaceae & $\begin{array}{l}\text { Gersoppa, Uttara Kannada, Karnataka. } \\
\text { Agumbe, Shimoga, Karnataka. }\end{array}$ & 3 & Endemic to Western Ghats - Maharashtra and Karnataka \\
\hline Zingiber neesanum (Graham) Ramam. & Zingiberaceae & Gersoppa, Uttara Kannada, Karnataka & 3 & Endemic to Western Ghats - Maharashtra, Kerala and Karnataka \\
\hline
\end{tabular}

